\title{
Assessing the impacts of the main river and anthropogenic use on the degree of metal contamination of oxbow lake sediments (Tisza River Valley, Hungary)
}

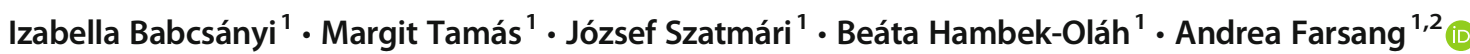

Received: 11 July 2019 / Accepted: 2 November 2019/Published online: 4 December 2019

(C) The Author(s) 2019

\begin{abstract}
Purpose Oxbow lakes, reaches that were cut off from a river during river straightening works, can accumulate during flooding metal-rich suspended sediments transported by a river from mining-impacted source areas and other anthropogenic sources. Additionally, the anthropogenic use of oxbow lakes may significantly impact the sediment-bound metal concentrations. The aim was to determine the dominating effect in the sediments' enrichment in heavy metals.

Materials and methods We collected surface sediments $(<10-\mathrm{cm}$ depth) from seven oxbow lakes once connected to the Tisza River (a transboundary river in Central and Eastern Europe). Four of the oxbows were located on the active floodplain, while three oxbows were at the reclaimed side (i.e., outside the flood defense levee). The sediment samples were subjected to total metal analyses $(\mathrm{Cd}, \mathrm{Co}, \mathrm{Cr}, \mathrm{Cu}, \mathrm{Ni}, \mathrm{Pb}$, and $\mathrm{Zn})$ and sequential chemical extractions.

Results and discussion Contamination indices (geoaccumulation index (Igeo) and pollution load index (PLI)) show a moderate but significant metal pollution of oxbow lakes situated on the active floodplain $\left(\mathrm{I}_{\text {geo }}(\mathrm{Pb})\right.$ 0.95-1.25, PLI 2.1-2.8) and an overall unpolluted to slightly polluted status of those at the reclaimed side $\left(\mathrm{I}_{\text {geo }}(\mathrm{Pb})-0.36-0.51\right.$, PLI 1.3-1.7). Additionally, the geochemical fractionation of the target metals showed that $\mathrm{Cd}$ and $\mathrm{Zn}$ were the most labile $(\mathrm{Cd} 29-48 \%$, $\mathrm{Zn} 18-37 \%$ of nonresidual proportions), indicating their environmental significance.

Conclusions Canonical discriminant analysis of the sediment-bound metal concentrations revealed the prevalent role of the river connection over the anthropogenic use in controlling the metal enrichment of oxbow sediments.
\end{abstract}

Keywords Flood $\cdot$ Floodplain $\cdot$ Heavy metal $\cdot$ Oxbow $\cdot$ Sediment $\cdot$ Tisza River

\section{Introduction}

Metals in rivers are derived from both natural and anthropogenic sources and can be transported far from their sources due to their close association with suspended sediments (Viers et al. 2009). Fluvial metal loads of anthropogenic origin often outweigh the load from the geochemical background in rivers flowing through industrial, urban, and in particular mining-

Responsible editor: Patrick Byrne

Andrea Farsang

farsang@geo.u-szeged.hu

1 Department of Physical Geography and Geoinformatics, University of Szeged, Egyetem u. 2-6., Szeged 6722, Hungary

2 Institute of Environmental Science and Technology, University of Szeged, Pf. 653., Szeged 6701, Hungary impacted areas (Liao et al. 2017; Zhang et al. 2017). During flood events, the metal load accumulated in fluvial bed sediments and associated riparian zones can be entrained, transported, and deposited downstream on the active floodplain (Foulds et al. 2014). Hence, rivers can be a major vector of the dispersal of metal contaminants (Ciazela et al. 2018).

The Tisza River, the longest tributary $(977 \mathrm{~km})$ of the Danube River, bears significant metal contamination due to the mining activity on its upper catchment area, as well as sewage and industrial discharges along its pathway (Bird et al. 2003). In the year 2000, two major mining accidents in the Tisza's upper catchment area released huge amounts of cyanide and heavy metals into the Tisza through its tributaries, damaging its ecosystem (Soldán et al. 2001). The impact of the cyanide and heavy metal spills on the flora and fauna of the Tisza has been extensively evaluated, as well as the metal contamination status of the river itself (Hum and Matschullat 2002; Bird et al. 2003; Fleit and Lakatos 2003; Lakatos et al. 2003; 
Óvári et al. 2004; Kraft et al. 2006; Woelfl et al. 2006; Osán et al. 2007; Sakan et al. 2009; Sakan and Đorđević 2010; Sakan et al. 2013; Simon et al. 2017). However, a limited number of studies focused on the impact of the metal-contaminated river on its active floodplain, and those studies are restricted to the Upper and the Middle Tisza regions (Black and Williams 2001; Szabó et al. 2008; Prokisch et al. 2009; Babka et al. 2011; Csedreki et al. 2011; Györi et al. 2015).

Around 70 larger oxbows ( $>5 \mathrm{ha}$ ) exist along the trajectory of the Tisza that were created by the river regulation works at the end of the nineteenth century. Oxbow lakes are natural wetlands providing breeding areas for threatened water bird species, as well as spawning grounds for many fish species, therefore several oxbows are Ramsar Convention Sites (e.g., Mártélyi floodplain and oxbow) (https://www.ramsar.org/ wetland/hungary). Besides their outstanding natural value, oxbow lakes play an important role in inland excess water storage and irrigation water storage, but also in providing recreational and fishing sites. Depending on the location of the disconnected reaches, two types of oxbow lakes can be distinguished: oxbows on the active floodplain and those outside the flood defense levee (at the reclaimed side). Those situated on the active floodplain act as sediment traps during flooding and can thus record the Tisza's pollution history (Nguyen et al. 2009). Oxbow lakes situated outside the levee are protected from flood waves, but can be hydraulically connected through irrigation channels and flood gates, to a limited extent. Therefore, we distinguished between these two types of oxbow lakes in order to study the impact of their situation and their connection with the main river on their contamination status. A recent study demonstrated that the frequent flooding of oxbow lakes by polluted rivers was responsible for the accumulation of metals $(\mathrm{Cd}, \mathrm{Cu}, \mathrm{Pb})$ in their sediments (Ciazela et al. 2018). On the other hand, the anthropogenic activity to which oxbows are subjected, such as fishing or sewage discharge, can significantly impact the quality of their sediments in terms of metal enrichment (Balogh et al. 2016). Therefore, we hypothesized that oxbow sediments can be enriched in metal pollutants to a variable level depending on the impact of their anthropogenic use and the degree of their connection with the main river.

Total metal concentrations alone do not provide sufficient information on the mobility and bioavailability, and hence the environmental impact, of the examined metal contamination. The harmful character of metals in aquatic environments depends not only on the degree of their enrichment, but also on the chemical form in which they occur. Sequential chemical extractions are widely used for determining the binding forms and the mobility of metals in soils and sediments (Gleyzes et al. 2002). Generally, in the absence of anthropogenic sources, sediment-bound trace metals are predominantly found in less labile forms, such as being incorporated into primary minerals (recovered in the residual fraction), while those introduced into soils and sediments from human sources tend to display higher mobility (de Andrade et al. 2010). Bird et al. (2003) has shown that the mining-related metals $(\mathrm{Cd}, \mathrm{Cu}$, $\mathrm{Pb}, \mathrm{Zn}$ ) in the stream sediments of the Tisza were principally partitioned into exchangeable, Fe/Mn oxides-bound and organic/sulfide-bound fractions following the mining accidents in 2000. The surface sediments in oxbow lakes on the active floodplain of the Tisza may also display high proportions of labile metal forms. In addition, the anthropogenic activity to which oxbows are subjected may also introduce labile metals into their sediments.

The aim of the present study was to (i) decipher which impact dominates (river connection vs anthropogenic use) in the oxbow sediments' enrichment in heavy metals and discuss their potential sources, and (ii) determine the mobility of the sediment-bound metals by sequential extractions.

\section{Materials and methods}

\subsection{Study area}

The studied oxbow lakes are located in the Lower Tisza region, between the confluence of the rivers Tisza and Körös and the Hungarian side of the Hungarian-Serbian border (Fig. 1). All of the seven studied oxbows were created during the Tisza's regulation at the end of the nineteenth century, when 112 meanders were cut off from the live river. Along with the cutting off of meanders, flood defense levees have been constructed along the riverbanks to protect the reclaimed areas. The superficial deposits of the Lower Tisza region on which the oxbows are formed are comprised mostly of Pleistocene loess and Holocene fluvial sediments (Mezősi 2011). Among the seven oxbow lakes included in this study, three are located on the active floodplain and four on the reclaimed side (i.e., outside the flood defense levee). Those on the active floodplain are the Mártélyi, the Sasér, and the Körtvélyesi oxbows. On the reclaimed side, the Csongrádi, the Atkai, the Nagyfai, and the Gyálai oxbows were investigated.

Table 1 shows the important characteristics of the studied oxbow lakes - namely their size, their connection with the Tisza, and their anthropogenic uses. Sediment dredging took place in three of the studied oxbow lakes, namely in the Csongrádi oxbow (in 2008-2009), in the Mártélyi oxbow (in 2002-2004), and in the Körtvélyesi oxbow (in 2007-2008). Another anthropogenic impact in some of the oxbows is the discharge of wastewater. Some wastewater leaking into the storm sewers $\left(\sim 10-20 \mathrm{~L} \mathrm{~s}^{-1}\right)$ occurred in Csongrád's sewer system and was discharged into the Csongrádi oxbow lake until 2003. During rainy periods, treated wastewater mixed with inland excess water is pumped into the Mártélyi oxbow lake $\left(40-60 \mathrm{~m}^{3} \mathrm{day}^{-1}\right)$. Treated wastewater of a nearby prison is permanently discharged into the Nagyfai oxbow. The 


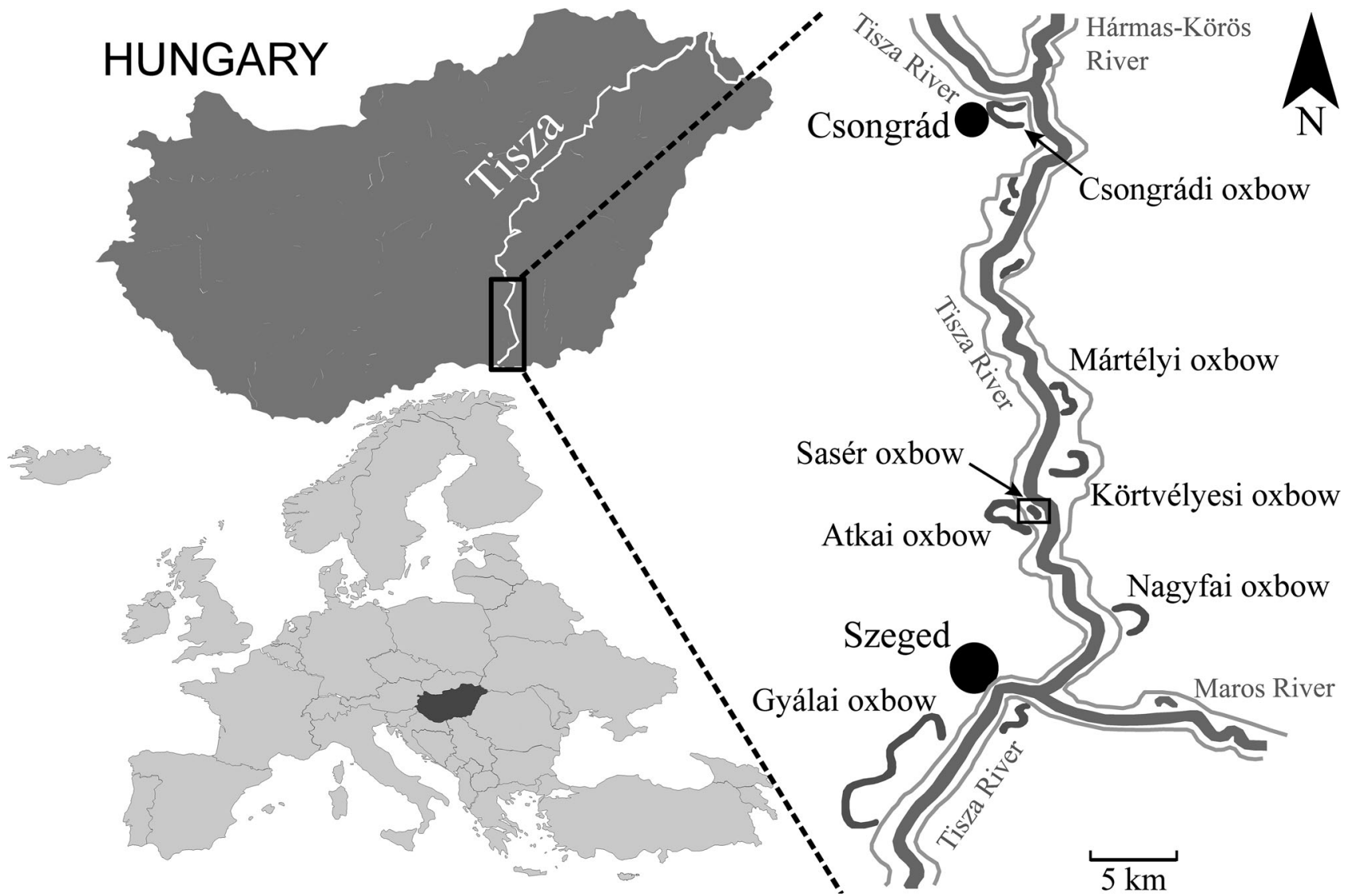

Fig. 1 The map of the sampling area showing the studied oxbow lakes in the Lower Tisza region (Hungary). The names of the oxbows not included in this study are not presented. The grey lines parallel to the Tisza River represent the flood defense levee

Gyálai oxbow is separated by dams and gates into three parts. The one closest to the city of Szeged ( 160,000 inhabitants) underwent the direct dumping of the city's untreated urban wastewater in the past. That part bears important heavy metal pollution in its sediments and was therefore not included in the present study. The other two parts that were included in the study are principally used for fishing. The Körtvélyesi oxbow is a protected lake with minimum human use. The Sasér and Atkai oxbows are two parts of one meander that have been cut off from the Tisza, and cut into two by the flood defense levee. The former is a protected oxbow, while the latter is used for fishing.

A land-cover map (Fig. 2) has been prepared for the active floodplain part of the Lower Tisza in the vicinity of the studied riparian oxbow lakes (Mártélyi, Körtvélyesi, Sasér) based on data from the Riparian Land Cover and Land Use product of Copernicus Initial Operations 2011-2013 using ArcGIS Online. The map shows that the main land cover in the vicinity of oxbows on the active floodplain is the broad-leaved forest with total cover density $>80 \%$ ( $61 \%$ of the active floodplain), followed by the transitional woodland and scrub category covering $13 \%$ of the assessed area and non-irrigated arable land (11\% of the studied area). The rest consists of managed grassland (9\%), inland marsh (1\%), and oxbow lakes (4\%).

\subsection{Sampling and laboratory analyses}

Sediment grab samples were collected in the superficial part (<10-cm depth) of the bottom sediments of oxbow lakes. The samples were collected every $0.5-1 \mathrm{~km}$ along the longitudinal banks at $\sim 1 \mathrm{~m}$ water depth and 2-3 $\mathrm{m}$ away from the oxbow bank using an Ekman-type sampler. Each sample is composed of six subsamples taken from a $1-\mathrm{m}^{2}$ area and homogenized to obtain a local composite sample. In the Gyálai oxbow, a single sample per sampling point was taken, with a higher spatial resolution along the two longitudinal banks of the oxbow to account for the potential urban impacts. Using heavy metal markers in a vertical sediment profile, Kiss and Sándor (2009) calculated average sedimentation rates on the active floodplain of the Middle Tisza and the Lower Tisza. The mean sedimentation rate for recent periods (1975-2006) is 1$1.5 \mathrm{~cm}$ year $^{-1}$. Hence, the top $10 \mathrm{~cm}$ collected from the bottom sediments of oxbow lakes on the active floodplain integrate roughly a decade. However, no data are available for the oxbow lakes situated outside the levee. Sediment sampling was carried out in 2003 in the Csongrádi and Mártélyi oxbows, in 2004 in the Nagyfai oxbow, and in 2006 in the Atkai, Saser, and Körtvélyesi oxbows. Additional sediment samples were collected in the Csongrádi, Mártélyi, Körtvélyesi, Sasér, 


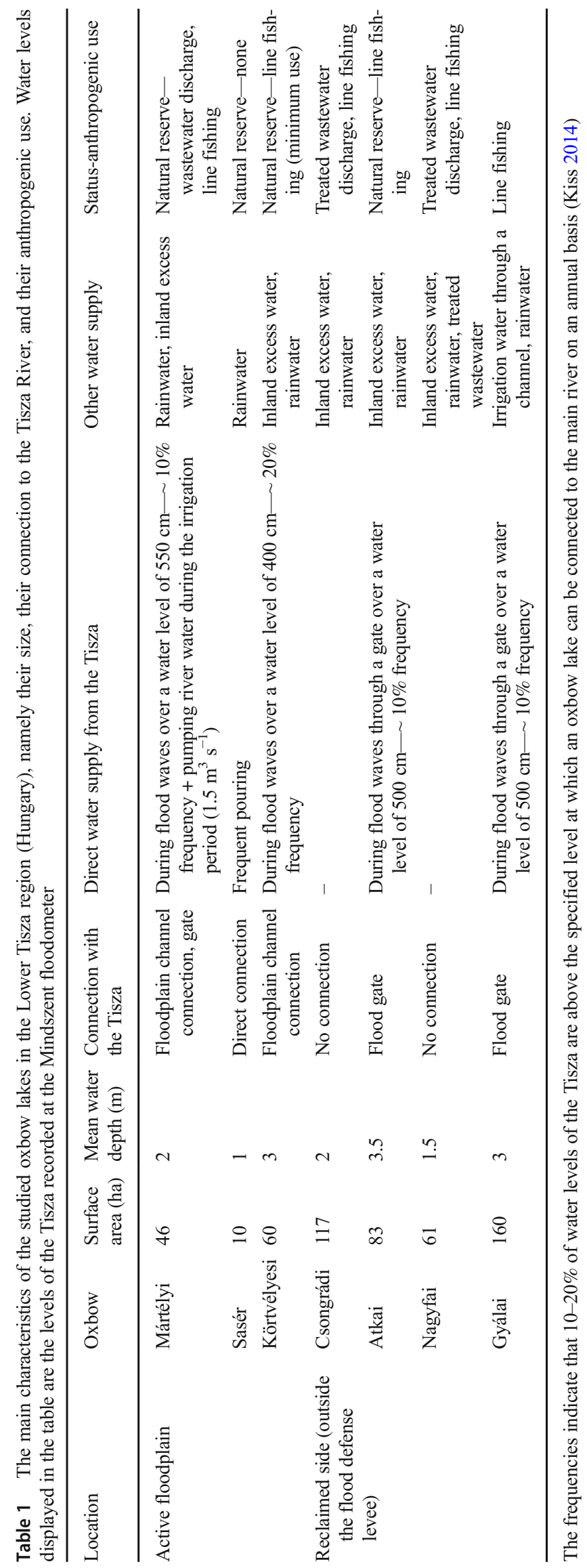




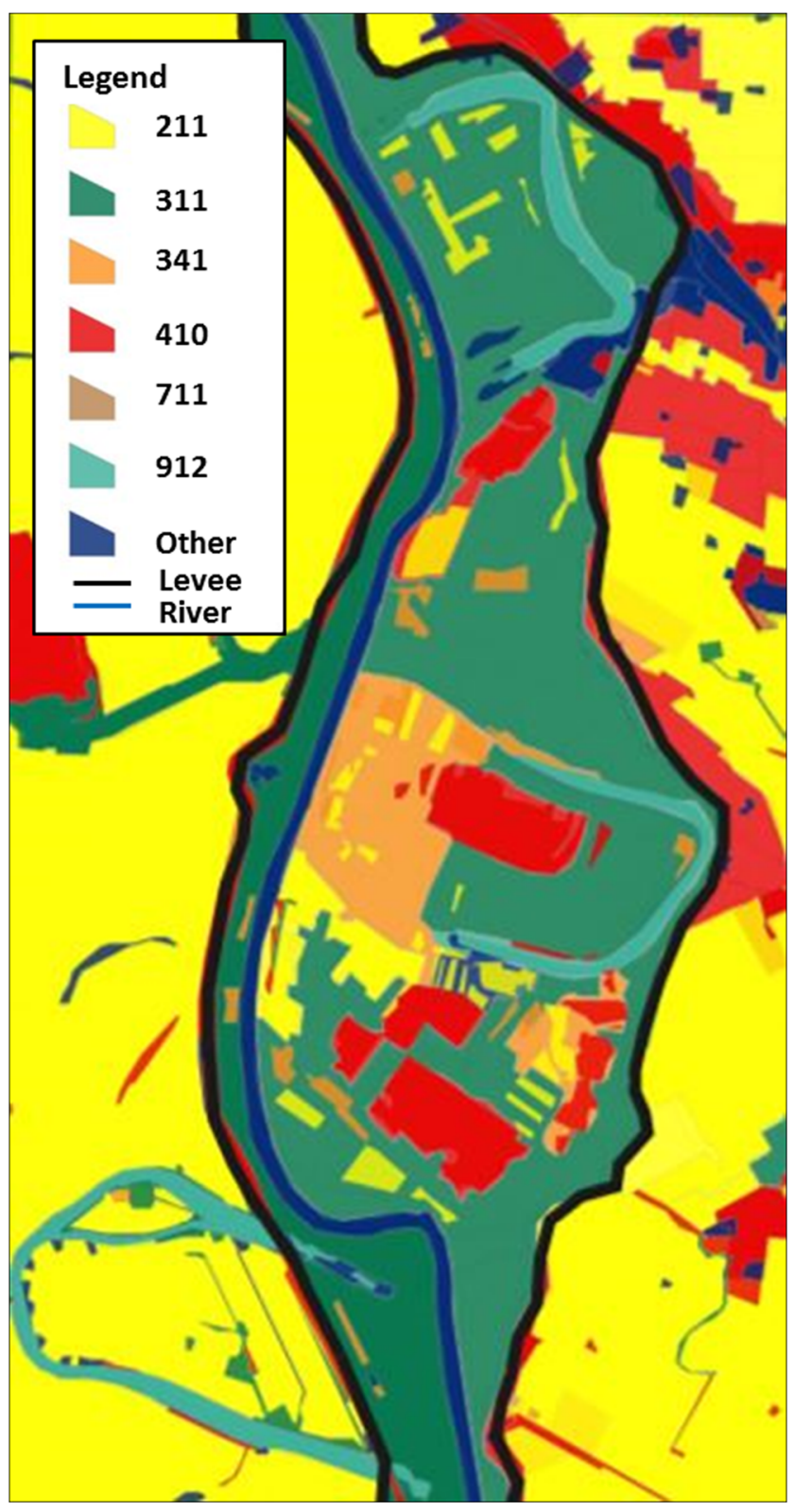

Fig. 2 The land cover map of the active floodplain at the Mártélyi oxbow, the Körtvélyesi oxbow, and the Sasér oxbow. 211: non-irrigated arable land; 311: broad-leaved forest with total cover density $>80 \%$; 341: transitional woodland and scrub; 410: managed grassland; 711: inland freshwater marsh; 912: separated water bodies belonging to the river system

Atkai, and the Nagyfai oxbows in 2011 for sequential extractions of heavy metals. Sediment samples from the Gyálai oxbow were not subject to sequential chemical extractions. For the study period (i.e., 2003-2011), the duration of flooding events ranged from a total of 9 days in 2011 (with flood levels of 520-650 cm) to 90 days in 2009 (with flood waves reaching $>650 \mathrm{~cm}$ ) (Kiss 2014). To our knowledge no significant pollution events occurred in the Tisza for the study period.

The pH (in KCl) (MSZ-08-0206/2:1978) ( $\pm 3 \%$ ), total nitrogen (Ntot) (MSZ 20135:1999) ( $\pm 10 \%)$, and organic matter content
(MSZ 21470-52:1983) $( \pm 15 \%)$ sediments were measured according to standard procedures. The sediment samples have been airdried as recommended in the Community Bureau of Reference (BCR) procedure (Ure et al. 1993). The samples were oven-dried at $105{ }^{\circ} \mathrm{C}$ for $12 \mathrm{~h}$ only prior to total method extraction by aqua regia and disaggregated in an agate mortar after removing larger organic debris and foreign material. The $<2$-mm bulk sediments have been treated for metal analyses. Sediment samples were digested in aqua regia (hydrochloric acid/nitric acid $=3: 1$ ) in closed vessels in a microwave oven (Anton Paar Multiwave 3000) as described in details elsewhere (Szolnoki and Farsang 2013). The slightly modified BCR sequential extraction method was applied for determining the geochemical fractionation and "mobility" of heavy metals in selected sediment samples as previously described in Ure et al. (1993) and Szolnoki and Farsang (2013). Briefly, the first fraction (1) was extracted with $0.11 \mathrm{M}$ acetic acid during $16 \mathrm{~h}$ of shaking; the second fraction (2) with $0.1 \mathrm{M}$ hydroxylammonium chloride, acidified with nitric acid to pH 2 (shaken for $16 \mathrm{~h}$ ); and the third fraction (3) with $8.8 \mathrm{M}$ hydrogen peroxide for $1 \mathrm{~h}$ at room temperature, then in a $85^{\circ} \mathrm{C}$ bath for an additional hour. We then added $0.1 \mathrm{M}$ ammonium acetate, adjusted with nitric acid to $\mathrm{pH} 2$ (shaken for $16 \mathrm{~h}$ ). The extract solution following each step was separated from the residue by centrifuging at $4000 \mathrm{rpm}(20 \mathrm{~min})$, then filtered $(<0.45 \mu \mathrm{m})$ and stored at $4{ }^{\circ} \mathrm{C}$ until analysis. The residue after each extraction step was washed with distilled water (shaken for $15 \mathrm{~min}$ ), centrifuged, and then the washing solution was discarded. The final residual phase (4) was dissolved in aqua regia at $180{ }^{\circ} \mathrm{C}$. Each sample was extracted twice to account for the reproducibility of the extraction method. Metal concentrations were analyzed by an atomic absorption flame furnace spectrometer (Perkin Elmer 3110 ) with a measurement uncertainty of $\pm 10 \%$. The procedure provided the partitioning of heavy metals into four phases: (1) exchangeable, (2) Fe/Mn oxides, (3) organic matter/sulfides, and (4) residual phase.

The sample treatment and metal analyses were done in a laboratory accredited by the National Accreditation Body of Hungary (member of the European Accreditation). For quality insurance, the laboratory regularly participates in interlaboratory comparisons for testing metal analyses in soils and sediments and procedural blanks as well as in-house standards are also regularly used and checked.

\subsection{Data analysis}

Pollution indices are widely applied to evaluate the enrichment of heavy metals from anthropogenic sources in a given geological medium (Jahan and Strezov 2018). Here, we used the metal pollution index (MPI) and the $\mathrm{I}_{\text {geo }}$ to compare the pollution status of oxbow sediments.

The $\mathrm{I}_{\text {geo }}$ was first introduced by Müller (1979) and was calculated following Eq. (1): 
$\mathrm{I}_{\text {geo }}=\log _{2}\left(\mathrm{C}_{\mathrm{n}} \times\left(1.5 \times \mathrm{B}_{\mathrm{n}}\right)^{-1}\right)$

where $\mathrm{Cn}$ is the concentration of the examined element in the sediment and $\mathrm{B}_{\mathrm{n}}$ is its geochemical background in the given medium. Müller (1979) classified the contamination level of the examined soil/sediment based on the $I_{\text {geo }}$ values as follows: $<0=$ uncontaminated, $0-1=$ uncontaminated to moderately contaminated, $1-2=$ moderately contaminated, and $2-$ $3=$ moderately to strongly contaminated. For the geochemical background metal concentrations, we applied those defined by Ódor et al. (1997). Those values were defined during the geochemical mapping in Hungary and represent average metal concentrations in the floodplain deposits.

The pollution load index (PLI) introduced by Tomlinson et al. (1980) indicates the overall enrichment of elements in the soils/sediments with respect to the background values (i.e., the average metal concentrations in floodplain deposits in Hungary) and is calculated following Eq. (2):

PLI $=\left(\mathrm{CF}_{1} \times \mathrm{CF}_{2} \times \mathrm{CF}_{3} \times \ldots \times \mathrm{CF}_{\mathrm{n}}\right)^{1 / \mathrm{n}}$

where $\mathrm{CF}$ stands for the concentration ratio of the examined metals $\mathrm{C}_{\text {metal }} / \mathrm{C}_{\text {background }}$ and $n$ corresponds to the number of examined metals. PLI is an indicator of the overall metalpollution degree of the studied soils/sediments. PLI values $>$ 1 indicate pollution, whereas $<1$ demonstrate no pollution.

The measured concentration data in the riparian oxbows and oxbows at the reclaimed side were compared using the unpaired non-parametric Wilcoxon signed rank test. The Spearman's rank correlation test (with a significance level of $p \leq 0.05$ ) was applied to determine associations in the metal concentration data. Canonical discriminant analysis was applied for exploring the effects of the degree of connection with the Tisza vs anthropogenic use of oxbows on the metal concentrations in the surface sediments of oxbows. The data distribution was examined with a QQ plot, and metal concentration data were log-transformed prior to performing the discriminant analysis. The pre-defined categories were based on the anthropogenic use of the oxbows: sewage-impacted, fishing, and protected oxbows. The tests were carried out using the SPSS software (IBM SPSS Statistics, Version 24).

\section{Results and discussion}

\subsection{Heavy metal contaminants in the surface sediments of oxbows: the effect of the degree of river connection vs anthropogenic use}

The impacts of the Tisza and the anthropogenic use of oxbow lakes on their sediment quality were examined by total metal concentration analyses and calculated pollution indices. Table 2 displays the total metal concentrations in the sediments of the studied oxbow lakes. Overall, higher concentrations of metals can be observed in the oxbow sediments situated on the active floodplain of the river compared to those at the reclaimed side. $\mathrm{Cd}\left(\geq 1 \mathrm{mg} \mathrm{kg}^{-1}\right), \mathrm{Zn}\left(\geq 200 \mathrm{mg} \mathrm{kg}^{-1}\right), \mathrm{Cu}\left(\geq 75 \mathrm{mg} \mathrm{kg}^{-1}\right)$, and Ni $\left(\geq 40 \mathrm{mg} \mathrm{kg}^{-1}\right)$ concentrations exceed the Hungarian standards for soils and sediments in oxbows situated on the active floodplain. The sediment-bound $\mathrm{Cr}$ concentrations $(\geq 75 \mathrm{mg}$ $\mathrm{kg}^{-1}$ ) are also above the legal limits in the Sasér oxbow, directly connected to the river. Most of the examined heavy metals are below that limit in oxbows situated at the reclaimed side, except for $\mathrm{Cd}$ in the Atkai oxbow and $\mathrm{Ni}$ in the Nagyfai and Gyálai oxbow lakes. Likewise, the pollution load indices (PLIs) as a measure of the overall metal pollution status of the oxbow sediments are significantly higher in the floodplain lakes $(\geq 2.1)$ compared to the reclaimed side (1.3 to 1.7) (Fig. 3). However, the PLI, as a measure of the degree of all-metal contamination, demonstrates a slight pollution of the oxbow lakes at the reclaimed side too, since all values exceed PLI $\geq 1$. The PLIs at the reclaimed side can reflect the anthropogenic activities to which those oxbows are subject. The highest sediment metal loads have been observed in the Sasér and the Mártélyi oxbows. Both oxbows are situated on the active floodplain and have the closest connection with the Tisza (Table 1). Indeed, the Sasér wetland experiences frequent pouring (almost a semi-lotic lake) from the river, while the Mártélyi oxbow enters into contact with the Tisza when its water level reaches $550 \mathrm{~cm}(\sim 10 \%$ frequency of the Tisza's water levels (Kiss 2014) (Table 1). Additionally, the Mártélyi oxbow's water is used for irrigation on nearby arable lands, and hence, its water is regularly renewed by pumping of the Tisza's water mainly during summertime (Table 1). The Körtvélyesi oxbow also situated on the active floodplain and displaying higher sediment metal loads can experience flooding from the Tisza through a channel connecting the river to the oxbow when the Tisza's level reaches $400 \mathrm{~cm}(\sim 20 \%$ frequency of the Tisza's water levels (Kiss 2014)) (Table 1). The oxbow lakes situated outside the levee on the reclaimed side have a limited contact with the Tisza. Indeed, the Csongrádi and the Nagyfai oxbows have no connection at all with the Tisza, while the water of the Atkai and the Gyálai oxbows can be renewed from the Tisza at a water level above $\sim 500 \mathrm{~cm}$ through flood gates (Table 1). Their limited connection with the Tisza is reflected in their lower sediment metal levels (Table 2). The overall tendency of heavy metal enrichment in riparian lake sediments shows the effect of their closer connection with the Tisza. On the other hand, the anthropogenic activities to which oxbows are subjected can also influence sediment metal loads in oxbow lakes (Balogh et al. 2016).

Canonical discriminant analysis was performed based on the sediment-bound $\mathrm{Cd}, \mathrm{Cu}, \mathrm{Pb}$, and $\mathrm{Zn}$ concentrations considering the predefined categories of oxbow lakes according to their anthropogenic use: sewage-impacted, fishing and protected oxbows (Fig. 4). The results of the discriminant analysis clearly show that the degree of sediment enrichment in heavy metals of oxbow lakes majorly depends on the extent of connection with 


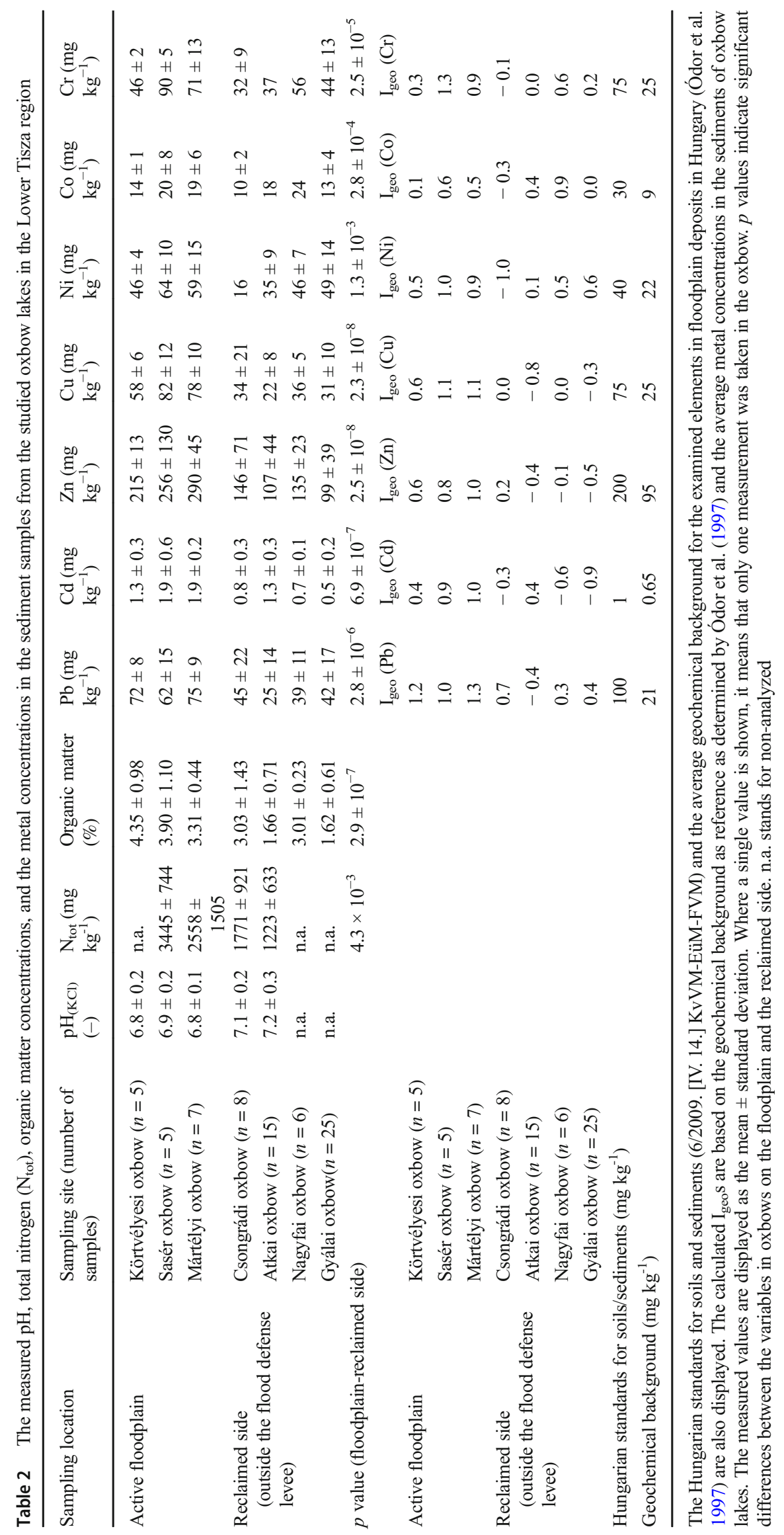


Fig. 3 The calculated geoaccumulation indices ( $\mathrm{I}_{\text {geo }}$ )and pollution load indices (PLI) in the studied oxbow sediments from the Lower Tisza region (Hungary). The oxbow lakes are compared based on their location, i.e., on the active floodplain of the Tisza River or at the reclaimed side

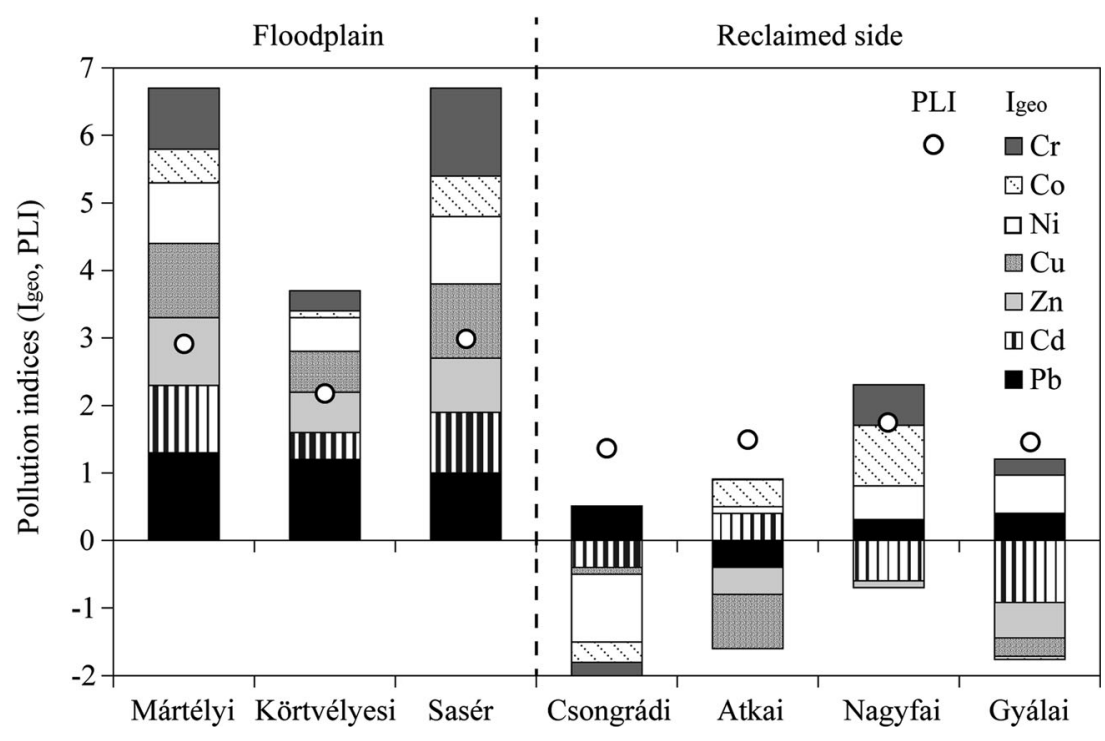

the Tisza (Fig. 4). Indeed, the anthropogenic use of the lakes seems to play a minor role in determining the sediment quality of oxbows, contrary to a previous study that showed the prevailing effect of anthropogenic use on the metallic concentrations of oxbow sediments (Balogh et al. 2016). In a recent study on the oxbows of the Odra River, a similar pattern has been highlighted, namely that the hydrologically connected and frequently flooded oxbow sediments were the most enriched in metal contaminants (Ciazela et al. 2018). The distribution of metals in the oxbow lakes is thus controlled by the degree of connection between the oxbow lakes and the Tisza and the river seems to be a major metal carrier.

\subsection{The sediment quality of oxbow lakes: metal contamination status and metal sources}

Three groups of metals can be distinguished based on the correlation coefficients: the $\mathrm{Pb}-\mathrm{Cu}-\mathrm{Zn}$ group, the $\mathrm{Ni}-\mathrm{Co}-\mathrm{Cr}$ group, while $\mathrm{Cd}$ displays only a limited correlation with other metals. The significant correlation observed for $\mathrm{Cu}, \mathrm{Pb}$, and $\mathrm{Zn}$ (Table 3) probably indicates their common origin as previously highlighted by studies conducted on the floodplain of the Upper Tisza (Prokisch et al. 2009; Csedreki et al. 2011). These elements are characteristic of low- to mediumtemperature hydrothermal ore deposits with some extreme values observed in the floodplain deposits of rivers discharging from Transylvania (Ódor et al. 1997). $I_{\text {geo }}$ for the $\mathrm{Pb}$ ranging from 1.0 to 1.3 show a significant $\mathrm{Pb}$ enrichment in the riparian oxbow sediments, while they are $<1$ in the lakes outside the levee (Table 2). Similarly, higher $\mathrm{I}_{\mathrm{geo}} \mathrm{S}$ have been calculated for $\mathrm{Cu}$ and $\mathrm{Zn}$ for the sediments in oxbows with a closer connection with the Tisza, compared those outside the levee (Table 2 ). The $\mathrm{I}_{\mathrm{geo}} \mathrm{S}>1$ show that anthropogenic sources of metals likely contribute to the sediment metal load. In the past, the Tisza experienced several severe pollution events that caused a significant enrichment of heavy metals in its channel sediments (Kraft et al. 2006). Prokisch et al. (2009) detected up to $410 \mathrm{mg} \mathrm{kg}^{-1} \mathrm{~Pb}, 2.38 \mathrm{mg} \mathrm{kg}^{-1} \mathrm{Cd}$,
Fig. 4 The canonical discriminant analysis shows that the anthropogenic use cannot explain the differentiation between oxbows based on the $\mathrm{Pb}$, $\mathrm{Zn}, \mathrm{Cu}$, and $\mathrm{Cd}$ concentrations in their sediments. The sedimentbound metal concentrations are better explained by the situation of oxbows, i.e., situated at the reclaimed side or on the active floodplain. The hollow symbols all represent sediment samples from oxbows at the reclaimed side, while the full symbols display samples from the riparian oxbows

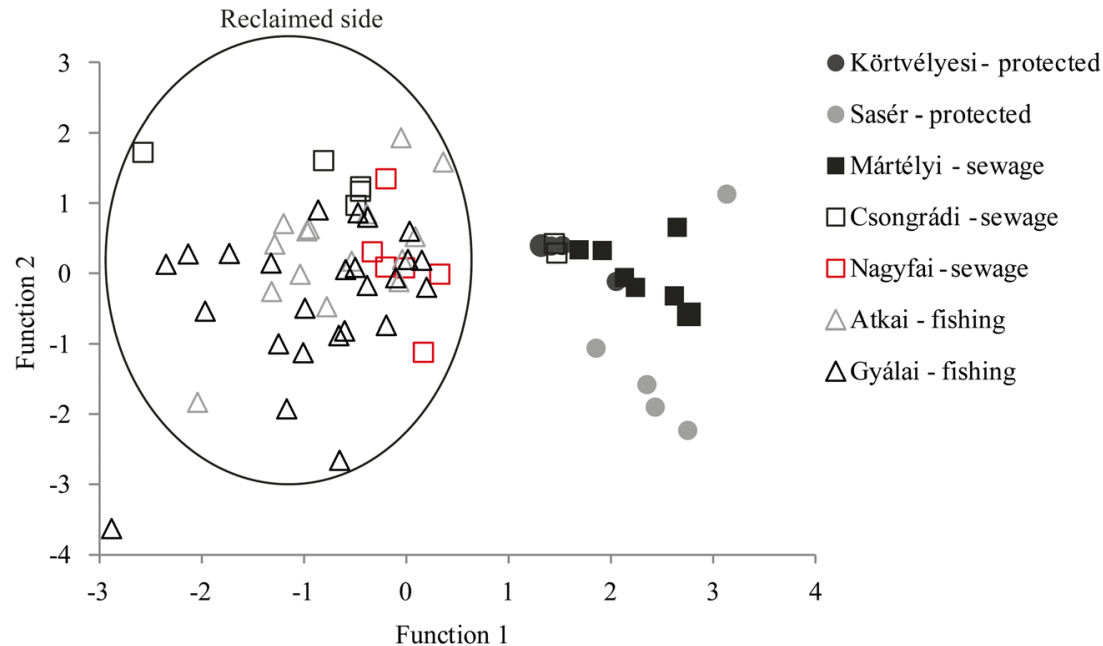


Table 3 The correlation coefficients (Spearman's rho) between the examined heavy metal concentrations in the surface sediments of oxbow lakes

\begin{tabular}{lllllll}
\hline & $\mathrm{Pb}$ & $\mathrm{Cd}$ & $\mathrm{Zn}$ & $\mathrm{Cu}$ & $\mathrm{Ni}$ & $\mathrm{Co}$ \\
\hline $\mathrm{Cd}$ & $0.279 *$ & & & & & \\
$\mathrm{Zn}$ & $0.853^{* *}$ & $0.543^{* *}$ & & & & \\
$\mathrm{Cu}$ & $0.909 * *$ & $0.369 * *$ & $0.902 * *$ & & & \\
$\mathrm{Ni}$ & $0.697 * *$ & 0.029 & $0.639 * *$ & $0.780^{* *}$ & & \\
$\mathrm{Co}$ & $0.392 * *$ & $0.387 * *$ & $0.563 * *$ & $0.631 * *$ & $0.772 * *$ & \\
$\mathrm{Cr}$ & $0.598^{* *}$ & $0.470^{* *}$ & $0.687 * *$ & $0.815^{* *}$ & $0.838^{* *}$ & $0.864 * *$ \\
\hline
\end{tabular}

*Correlation is significant at the 0.05 level

**Correlation is significant at the 0.01 level

$572 \mathrm{mg} \mathrm{kg}^{-1} \mathrm{Zn}$, and $193 \mathrm{mg} \mathrm{kg}^{-1} \mathrm{Cu}$ in sediments deposited on the active floodplain of the Upper Tisza by a flood wave following mine tailings dam failure accidents in 2000. Those accidents consisted of dumping large quantities of cyanide and heavy metals into the Viseu and Szamos rivers, which are tributaries of the Tisza in its upper catchment. The metal distribution in the Tisza's channel sediments displayed a decreasing concentration pattern with the flow direction (Bird et al. 2003; Fleit and Lakatos 2003; Kraft et al. 2006). The recurrent peaks in the concentration depth profile of these metals $(\mathrm{Pb}, \mathrm{Cu}, \mathrm{Zn})$ in riparian oxbow sediments of the Upper Tisza suggests that heavy metal pollution events archived in the sediment layers take place every now and then in the catchment of the Upper Tisza, and the pollution is still ongoing to a lesser extent (Nguyen et al. 2009; Balogh et al. 2017). Besides the mining industry, the higher geochemical background of these metals in the Tisza's upper catchment can also explain the increased metal concentrations in oxbows situated on the active floodplain of the Lower Tisza. Indeed, during the geochemical mapping of Hungary by Ódor et al. (1997) found that higher concentration values of $\mathrm{Cu}, \mathrm{Pb}$, and $\mathrm{Zn}$ were associated with the floodplain deposits in the upper catchment of the Tisza. On the other hand, additional sources of $\mathrm{Cu}, \mathrm{Pb}$, and $\mathrm{Zn}$ may also contribute to the sediment metal load. Some of its tributaries may add significant amounts of metal loads to the Tisza. The Maros River bears high metal concentrations of $\mathrm{Cu}, \mathrm{Pb}$, and $\mathrm{Zn}$ in its channel sediments and hence causes an increase in the sediments of the Tisza downstream to their confluence (Hum and Matschullat 2002). Additionally, these metals can also be present in wastewater and biosolids, which likely contributes to the metal load in the Mártélyi wastewater impacted oxbow.

The other group of elements consists of $\mathrm{Co}, \mathrm{Cr}$, and $\mathrm{Ni}$ based on correlation tests. The $\mathrm{I}_{\mathrm{geo}} \mathrm{s}$ for $\mathrm{Ni}$ and $\mathrm{Cr}$ range from 0.3 to 1.3 for riparian oxbows, and from -1.0 to 0.6 at the reclaimed side (i.e., outside the flood defense levee) (Table 2). At the reclaimed side, none of the studied metals exceeds $\mathrm{I}_{\text {geo }}$ $\geq 1$, which reflects their overall unpolluted status and the mainly geogenic origin of metals. The highest $\mathrm{I}_{\text {geo }}$ values were found in the Nagyfai oxbow ( $>0.5$ ) for $\mathrm{Co}, \mathrm{Cr}$, and $\mathrm{Ni}$, suggesting some anthropogenic impacts on its sediment quality, i.e., treated wastewater dumping. The latter two elements do not exceed the Hungarian quality standards for soils and sediments and are probably of geogenic origin in the majority of studied oxbow lakes; however, in the Sasér and the Mártélyi oxbow lakes, elevated $\mathrm{Cr}$ concentrations were observed (Table 2). The Ni enrichment in the Nagyfai and Gyálai oxbows exceeding the Hungarian standards is most probably of anthropogenic origin, since the former receives treated wastewater, while the latter experienced wastewater dumping from an electroplating plant through a channel in the past.

Similarly to the other discussed metals, Cd also displays higher $\mathrm{I}_{\mathrm{geo}} \mathrm{s}$ in the sediments of riparian oxbows (Table 2). Application of certain phosphatic fertilizers that can inadvertently add some $\mathrm{Cd}$ to the sediments of the Atkai oxbow, situated outside the levee may explain the observed higher Cd contents compared to the other oxbows at the reclaimed side.

Similarly to metals, $\mathrm{N}_{\text {tot }}$ and organic matter contents tend to be higher in oxbow lake sediments on the river floodplain (Table 1), which can be attributed to occasional inputs from the river during flooding. Conversely, we previously found higher concentrations of the dissolved species of nitrogen and organic carbon in the lakes situated at the reclaimed side compared to riparian oxbows (Tamás and Farsang 2011). These results are in accord with a study conducted in oxbow lakes in the Upper Tisza region, an observation explained by the condensation of the dissolved species in those lakes through evaporation of the lake water and the lack of occasional water renewal from the main river (Babka and Szabó 2007). Consequently, the Tisza has an ambiguous effect on the environmental status of the riparian oxbow lakes. Although it can negatively impact their sediment quality by enriching them in heavy metals, on the other hand the occasional flooding by the river creates regular water renewal in oxbows that improves their water quality.

\subsection{Mobility of sediment-bound heavy metals in oxbows of the Lower Tisza valley}

The observed total concentrations of metals indicate a moderate pollution of the oxbow lakes situated on the Tisza's active floodplain. However, they do not relate to the mobility and availability of metals that ultimately determine the ecological risk they pose. Even though sequential chemical extractions of heavy metals do not directly indicate the speciation of metals in soils and sediments, precious data can be obtained about their mobility and bioavailability (Pueyo et al. 2008; Fernández-Ondoño et al. 2017). Figure 5 displays the results of the sequential extractions of heavy metals in the studied oxbow sediments. According to our results, the most labile 
a

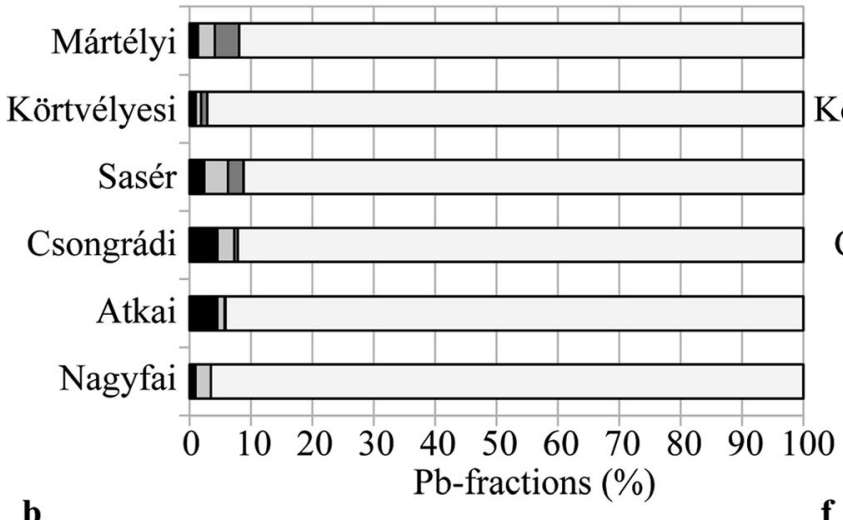

b

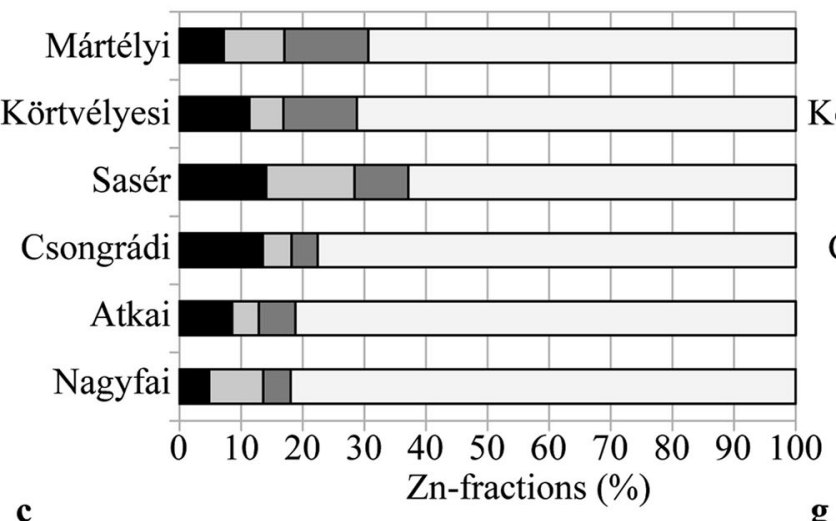

g

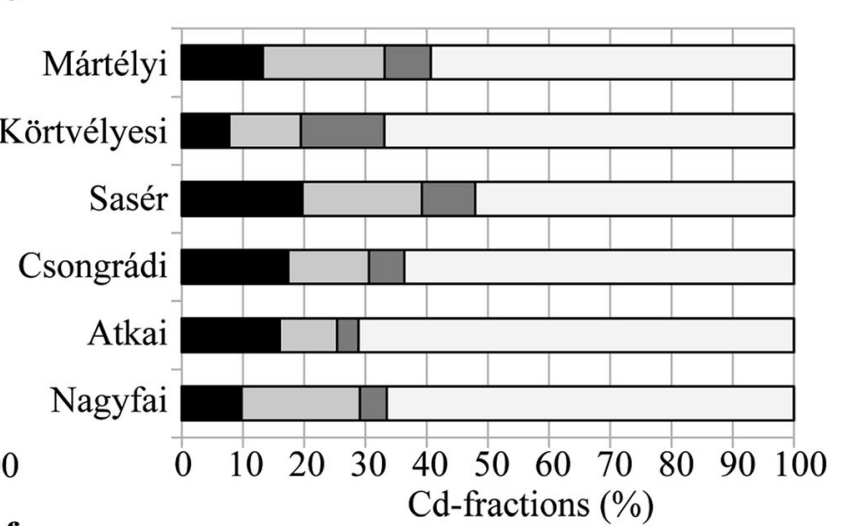

f

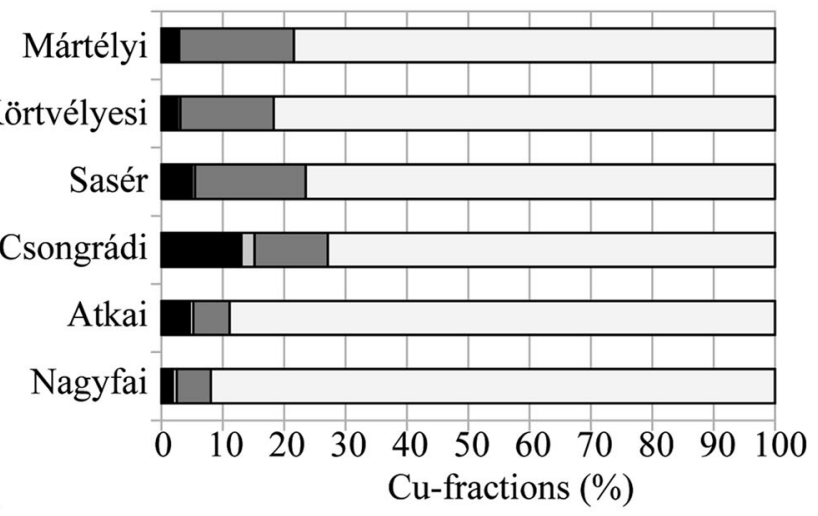

Mártélyi

Körtvélyesi

Sasér

Csongrádi

\section{Atkai}

Nagyfai

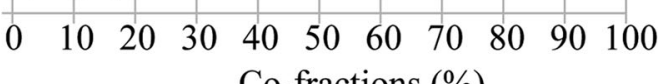

Ni-fractions (\%)

Co-fractions (\%)

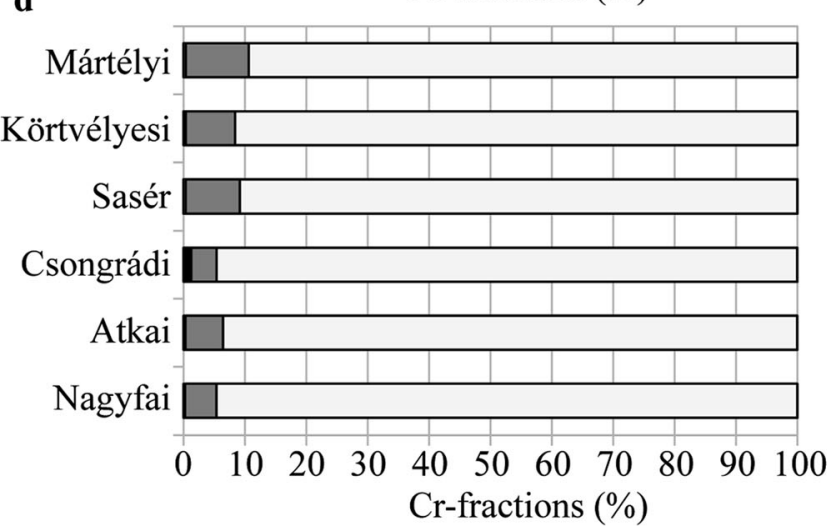

Fig. 5 The geochemical fractionation of the target sediment-bound heavy metals: $\mathrm{Pb}(\mathbf{a}), \mathrm{Zn}(\mathbf{b}), \mathrm{Ni}(\mathbf{c}), \mathrm{Cr}(\mathbf{d}), \mathrm{Cd}(\mathbf{e}), \mathrm{Cu}(\mathbf{f}), \mathrm{Co}(\mathbf{g})$ in the studied oxbow lakes of the Lower Tisza region (Hungary) as assessed by

sequential chemical extractions of one composite sample per site. The presented data are averages of two replicates of the same sample 
metals in the studied oxbows are $\mathrm{Cd}$ and $\mathrm{Zn}$, with 29 to $48 \%$ and 18 to $37 \%$ in the extractable fractions, respectively (exchangeable $+\mathrm{Fe} / \mathrm{Mn}$ oxides + organic matter/sulfide fractions). The least mobile metals are $\mathrm{Cr}$ and $\mathrm{Pb}$, displaying 5 to $11 \%$ and 3 to $9 \%$ of non-residual proportions, respectively. The order of metal mobility of the studied oxbow sediments is $\mathrm{Cd}>\mathrm{Zn}>\mathrm{Cu}>\mathrm{Ni}>\mathrm{Co}>\mathrm{Cr}>\mathrm{Pb}$. Statistically, only $\mathrm{Zn}$ shows a significant difference in its extractable proportions $(p$ value $<0.05$ ) between the riparian oxbows and oxbows at the reclaimed side. Similarly, higher $\mathrm{Pb}$ and $\mathrm{Zn}$ proportions were found in sediments freshly deposited on the floodplain following a contaminated flood wave (after the tailings dam failure accidents in 2000) in the Upper Tisza catchment (Alapi and Györi 2003). Therefore, $\mathrm{Zn}$ in the riparian oxbows of the Lower Tisza valley may in part incorporate "freshly" added $\mathrm{Zn}$ from anthropogenic sources like the mining area in the upper catchment as well as coal, and waste combustion and steel processing. Foodstuffs, drinking water and wastewater also contain non-negligible concentrations of $\mathrm{Zn}$ (Wuana and Okieimen 2011). However, at the confluence of the Maros a significant increase in the $\mathrm{Zn}$ metal load has been evidenced in the bottom sediments of the Tisza (Hum and Matschullat 2002). In a previous study conducted in 2000 following the heavy metal spills at the mining source (in the Lapus River), mining-related metals $(\mathrm{Cd}, \mathrm{Cu}, \mathrm{Pb}, \mathrm{Zn})$ were predominantly partitioned in the organic matter/sulfide fraction $(\sim 100 \%)$, suggesting their presence in sulfide-bound forms (Bird et al. 2003). The same study highlighted that $\mathrm{Cd}$ and $\mathrm{Zn}$ displayed the highest proportions of labile metal forms in the sediments of the Tisza, and even at its lower reaches, $>60 \%$ of $\mathrm{Cd}$ and $>$ $30 \%$ of $\mathrm{Zn}$ were present in the exchangeable fraction. The freshly added heavy metals coming from anthropogenic sources into soils and sediments are often found in a more labile form compared to the geogenic and previously buried metal portions (Pueyo et al. 2008). Following their burial in sediments, heavy metals go through a process called aging or natural attenuation that results in their stronger adhesion to the sediment constituents (Zhang et al. 2014). For instance, $\mathrm{Cu}$ has been found to go through aging that results in its stronger adhesion to the sediment constituents over time under both aerobic (e.g., soils) and anaerobic conditions (e.g., anoxic sediments) (Ma et al. 2006; Babcsányi et al. 2017). Release of these stable heavy metals from oxbow sediments is expected to be limited unless dramatic changes (e.g., $\mathrm{pH}$ or redox) in the sediments' physicochemical conditions occur. Hence, the target metals are supposed to stay immobile, and pose only a limited ecological risk in oxbow lakes.

Our results indicate that the exchangeable and $\mathrm{Fe} / \mathrm{Mn}$ oxides-bound fractions represent $\sim 30 \%$ of the total $\mathrm{Cd}$ in the sediments. Bird et al. (2003) found that following the accidental spills, $\mathrm{Cd}(\geq 65 \%)$ was predominantly partitioned in the exchangeable phase in the Tisza's stream sediments even at its lower reaches (in the Lower Tisza) using a similar sequential extraction procedure. Identically to our data, $\mathrm{Cd}$ was the most labile among the mining-related metals (i.e., $\mathrm{Cd}, \mathrm{Cu}, \mathrm{Pb}$, and $\mathrm{Zn})$. This means that a significant portion of $\mathrm{Cd}$ is present in the stream sediments, and likely in the suspended particles, and thus can be migrated by the river far from its pollution sources in both dissolved and particulate-bound forms. Some smaller tributaries and the Maros River also contribute to the Tisza's channel sediments' Cd load (Hum and Matschullat 2002). Additionally, anthropogenic $\mathrm{Cd}$ sources can enter the oxbow lakes, such as $\mathrm{Cd}$ from phosphate fertilizers and pesticides used on agricultural fields in the surroundings of oxbows (see Fig. 2 for land use), as well as traffic-related Cd (Wuana and Okieimen 2011).

The second target metal displaying important lability is the $\mathrm{Zn}$, with an average of $10 \%$ in both the exchangeable and the $\mathrm{Fe} / \mathrm{Mn}$ oxides-bound fractions in the surface sediments of riparian oxbows. For comparison, the stream sediments in the Lower Tisza contained 36\% exchangeable and $38 \% \mathrm{Fe} / \mathrm{Mn}$ oxides-bound $\mathrm{Zn}$ (Bird et al. 2003), showing that metal spills release highly mobile $\mathrm{Zn}$ into the river. Cadmium and $\mathrm{Zn}$ have been shown to be relatively mobile and readily bioavailable in river and floodplain sediments (Salomons and Förstner 1984). Hence, their environmental significance is non-negligible.

In the case of $\mathrm{Cu}$, the acid-soluble fraction represents 2 $13 \%$ and the organically or sulfide-bound fraction $6-19 \%$, while the $\mathrm{Fe} / \mathrm{Mn}$ oxides-bound phase is negligible $(\leq 2 \%)$. Much of the $\mathrm{Cu}$ present in oxbow sediments is found in the residual fraction $(\geq 73 \%)$. Copper in anoxic sediments is typically found in precipitated sulfides $\left(\mathrm{Cu}_{\mathrm{x}} \mathrm{S}\right)$, similarly to other chalcophile metals (Pb, Cd) (Hofacker et al. 2013) that are partly extracted by the applied hydrogen peroxide treatment in the organically/sulfide-bound fraction. Indeed, in environments deprived of oxygen, such as in oxbow sediments, $\mathrm{Cu}$ forms a variety of sulfides with and without $\mathrm{Fe}$ (pyritization) that can only be dissolved with nitric acid at the final stage of the extraction procedure (i.e., in the residual phase) (Morse and Luther 1999). The precipitated $\mathrm{Cu}$-sulfides may only be re-mobilized by oxygenation of sediments, for instance during sediment dredging. Therefore, the dredged sediments during oxbow rehabilitation works should be carefully managed.

Hardly any $\mathrm{Pb}$ was extracted in the acid soluble, reducible, and oxidizable fractions. More than $91 \%$ is present in the oxbow sediments as residual $\mathrm{Pb}$. This contradicts previous findings according to which $\mathrm{Pb}$ stays mainly $\mathrm{Fe} / \mathrm{Mn}$ oxidesbound and organically/sulphides-bound in the stream sediments of the mining-affected tributaries of the Tisza, even several years after the mine tailings dam failures (Bird et al. 2008). It has also been demonstrated that $\mathrm{Pb}$, similarly to $\mathrm{Cu}$ and $\mathrm{Cd}$, is sequestered in sulfide precipitates in anoxic conditions even under sulfate limitation (Weber et al. 2009). However, the lack of selectivity of the applied sequential chemical extractions with regards to sulfides may partly explain the discrepancy with previous results (Peltier et al. 
2005). Nonetheless, the results indicate that $\mathrm{Pb}$ is not of environmental concern in the studied oxbow lakes, as it is fairly hard to dissolve from their sediments.

\subsection{Metal enrichment of the Tisza River basin-comparison between the Upper, the Middle, and the Lower Tisza regions}

Our results have been compared with data from oxbow lakes in the Upper Tisza region to assess the overall degree of contamination of the Tisza basin. Comparing the calculated $\mathrm{I}_{\text {geo }}$ and PLI indices in both riparian and reclaimed oxbow sediments, we can observe a pronounced difference in the degree of contamination of oxbows, depending on their degree of connection to the Tisza (Babka 2013; Balogh et al. 2016) at both the upper and lower sections of the river basin (Table 4). The anthropogenic use (i.e., fishing, sewage discharge, protected) of the lakes plays a secondary role in determining the metal-pollution degree of oxbow sediments (Balogh et al. 2016). Surprisingly, however, there is no marked decrease in the metal contamination degree of the oxbows situated on the active floodplain from the Upper Tisza to the Lower Tisza region. The sediment dredging that affected three oxbow lakes at the Lower Tisza during the study period cannot be at the origin of the observed metal distribution patterns, as sampling for total metal analyses was performed in each oxbow lake before dredging. This pattern of heavy metal distribution in periodically flooded oxbow sediments suggests that additional metal sources probably contribute to sediment metal levels in oxbow lakes. Additional contributions through the discharge from wastewater treatment plants near settlements (e.g., Szolnok, Csongrád), as well as from tributaries at the lower reaches of the Tisza are probably at the origin of the lack of a downstream dilution pattern. Indeed, according to the findings of several studies performed in the Tisza's lower reaches (Black and Williams 2001; Hum and Matschullat 2002; Sakan et al. 2009), no significant downstream decrease of the heavy metal contaminant concentrations can be observed from the Middle to the Lower Tisza valley. On the contrary, raising concentrations of $\mathrm{Cd}, \mathrm{Cu}, \mathrm{Pb}$, and $\mathrm{Zn}$ downstream to the confluence with the Maros (Mures) River, and in particular downstream to the city of Szeged, have been measured in the river sediments. These results further support the idea of supplementary sources of the river's metal load at its lower reaches in addition to the Tisza's upper catchment originating from a higher geochemical background and the mining industry.

\section{Conclusions}

Overall, a significant metal enrichment is observed in the riparian oxbow lakes compared to those outside the flood defense levee. The average concentration values of $\mathrm{Cd}, \mathrm{Cu}, \mathrm{Ni}$, and $\mathrm{Zn}$ of the sediments in all riparian oxbow lakes exceed the legal standards established for soils and sediments (according to the Hungarian legislation). At the reclaimed side, only $\mathrm{Cd}$ in one and $\mathrm{Ni}$ in two oxbows are above those environmental quality standards. Based on the results of the sequential extractions, it can be concluded that only Zn displays significantly higher labile proportions in the sediments of the riparian oxbows compared to the reclaimed side. Overall, contamination indices reveal a moderate metal pollution of oxbow lakes on the floodplain, and an unpolluted to slightly polluted status of oxbow lakes at the reclaimed side.

Rivers that drain areas impacted by mining, such as the Tisza, significantly affect the degree of metal enrichment in the sediments of connected oxbow lakes. Previously, the

Table 4 The geoaccumulation indices $\left(\mathrm{I}_{\text {geo }}\right)$ in the live Upper Tisza and in oxbow lake sediments from the Upper Tisza and the Lower Tisza regions (Hungary), calculated based on heavy metal concentration data from Balogh et al. (2016) and Babka (2013)

\begin{tabular}{|c|c|c|c|c|c|c|c|c|c|}
\hline Study area & $\mathrm{I}_{\text {geo }}(\mathrm{Pb})$ & $\mathrm{I}_{\mathrm{geo}}(\mathrm{Zn})$ & $\mathrm{I}_{\text {geo }}(\mathrm{Cu})$ & $\mathrm{I}_{\mathrm{geo}}(\mathrm{Cr})$ & $\mathrm{I}_{\text {geo }}(\mathrm{Cd})$ & $\mathrm{I}_{\mathrm{geo}}(\mathrm{Ni})$ & $\mathrm{I}_{\mathrm{geo}}(\mathrm{Co})$ & PLI (Pb, Zn, Cu, Cr) & $\begin{array}{l}\mathrm{PLI}(\mathrm{Pb}, \mathrm{Zn}, \mathrm{Cu}, \\
\mathrm{Cr}, \mathrm{Ni}, \mathrm{Co}, \mathrm{Cd})\end{array}$ \\
\hline Upper (live) Tisza (Babka 2013) & 1.3 & 1.8 & 0.3 & -1.1 & 1.5 & 0.7 & 0.3 & 2.26 & 2.44 \\
\hline $\begin{array}{l}\text { Upper Tisza floodplain ox. } \\
\text { (Balogh et al. 2016) }\end{array}$ & 1.4 & 0.5 & 0.7 & 0.9 & - & - & - & 2.75 & - \\
\hline $\begin{array}{l}\text { Upper Tisza floodplain ox. } \\
\text { (Babka 2013) }\end{array}$ & 1.5 & 0.7 & -0.3 & -0.2 & 0.9 & 1.1 & 0.4 & 2.03 & 2.25 \\
\hline $\begin{array}{l}\text { Lower Tisza floodplain ox. } \\
\text { (this study) }\end{array}$ & 1.2 & 0.7 & 0.9 & 0.9 & 0.7 & 0.7 & 0.4 & 2.84 & 2.59 \\
\hline $\begin{array}{l}\text { Upper Tisza reclaimed side ox. } \\
\text { (Babka 2013) }\end{array}$ & 0.9 & -0.3 & -0.7 & -0.7 & 0.2 & 0.6 & 0.2 & 1.31 & 1.53 \\
\hline $\begin{array}{l}\text { Lower Tisza reclaimed side ox. } \\
\text { (this study) }\end{array}$ & 0.2 & -0.4 & -0.3 & 0.1 & -0.3 & 0.4 & -0.1 & 1.42 & 1.45 \\
\hline
\end{tabular}

Note that the geo-accumulation indices in oxbows from the Upper Tisza region, based on data from Babka (2013), were calculated from the median concentration values of heavy metals in surface sediment samples $(0-10 \mathrm{~cm})$ collected in 2010 . Geoaccumulation indices based on mean heavy metal concentration data from Balogh et al. (2016) were measured in surface sediment samples (0-2 cm) collected in 2013. The pollution load indices (PLIs) are also displayed 
beneficial impacts of the river flooding on the water quality of oxbow lakes have been shown. However, the spreading and dispersal of metal-bearing particles may limit the advantageous effects of the Tisza's flood waves on the environmental quality of those oxbows. We can also highlight that the extent of river connection of oxbow lakes determines the degree of the sediments' metal enrichment and outweighs the impact of their anthropogenic use. Floodplain storage of heavy metals, in particular in the low energy sedimentation zones such as oxbows, is a significant process in the metal distribution pattern in the fluvial landscape of the Tisza basin. The main sources of the target metals (i.e., $\mathrm{Cd}, \mathrm{Cu}, \mathrm{Pb}$, and $\mathrm{Zn}$ ) are probably their higher geochemical background and the mining industry at the Tisza's upper catchment; however, further inputs apparently contribute to the river metal load at its lower reaches.

Acknowledgments Izabella Babcsányi is grateful for support of the Premium Postdoctoral Fellowship Program of the Hungarian Academy of Sciences. The authors appreciate that their colleagues of the Lower Tisza District Water Directorate have shared data and information about the studied oxbow lakes. We wish to thank István Fekete and Ibolya Tápai for their kind assistance with the analytical work.

Funding information Open access funding provided by University of Szeged (SZTE).

\section{Compliance with ethical standards}

Conflict of interest The authors declare that they have no conflict of interest.

Open Access This article is distributed under the terms of the Creative Commons Attribution 4.0 International License (http:// creativecommons.org/licenses/by/4.0/), which permits unrestricted use, distribution, and reproduction in any medium, provided you give appropriate credit to the original author(s) and the source, provide a link to the Creative Commons license, and indicate if changes were made.

\section{References}

Alapi K, Györi Z (2003) Investigating the heavy metal-loaded floodplain sediments of the River Tisza. Acta Agraria Debreceniensis, pp 1-6

Babcsányi I, Meite F, Imfeld G (2017) Biogeochemical gradients and microbial communities in Winogradsky columns established with polluted wetland sediments. FEMS Microbiol Ecol https://doi.org/ 10.1093/femsec/fix089

Babka B (2013) Complex environmental analytical examination of the Upper-Tisza River and its oxbow lakes. University of Debrecen, Hungary, Dissertation

Babka B, Szabó S (2007) Water chemical analysis of the oxbow lakes near the Upper-Tisza River. Acta Geographica Debrecina Landscape Environ 1:36-42

Babka B, Futó I, Szabó S (2011) Clustering oxbow lakes in the UpperTisza Region on the basis of stable isotope measurements. J Hydrol 410:105-113
Balogh Z, Harangi S, Kundrát JT, Gyulai I, Tóthmérész B, Simon E (2016) Effects of anthropogenic activities on the elemental concentration in surface sediment of oxbows. Water Air Soil Pollut 227:13

Balogh Z, Harangi S, Gyulai I, Braun M, Hubay K, Tóthmérész B, Simon E (2017) Exploring river pollution based on sediment analysis in the Upper Tisza region (Hungary). Environ Sci Pollut Res 24:48514859

Bird G, Brewer PA, Macklin MG, Balteanu D, Driga B, Serban M, Zaharia S (2003) The solid state partitioning of contaminant metals and As in river channel sediments of the mining affected Tisa drainage basin, northwestern Romania and eastern Hungary. Appl Geochem 18:1583-1595

Bird G, Brewer PA, Macklin MG, Balteanu D, Serban M, Driga B, Zaharia S (2008) River system recovery following the Novaț-Roşu tailings dam failure, Maramureș County, Romania. Appl Geochem 23:3498-3518

Black MC, Williams PL (2001) Preliminary assessment of metal toxicity in the middle Tisza river (Hungary) flood plain. J Soils Sediments 1: 213-216

Ciazela J, Siepak M, Wojtowicz P (2018) Tracking heavy metal contamination in a complex river-oxbow lake system: Middle Odra Valley, Germany/Poland. Sci Total Environ 616-617:996-1006

Csedreki L, Csatári I, Szabó S (2011) Study of heavy metal pollution of the Upper-Tisza floodplain using XRF techniques. Studia Universitatis "Vasile Goldis" 21:101-107

Fernández-Ondoño E, Bacchetta G, Lallena AM, Navarro FB, Ortiz I, Jiménez MN (2017) Use of BCR sequential extraction procedures for soils and plant metal transfer predictions in contaminated mine tailings in Sardinia. J Geochem Explor 172:133-141

Fleit E, Lakatos G (2003) Accumulative heavy metal patterns in the sediment and biotic compartments of the Tisza watershed. Toxicol Lett 140-141:323-332

Foulds SA, Brewer PA, Macklin MG, Haresign W, Betson RE, Rassner SME (2014) Flood-related contamination in catchments affected by historical metal mining: An unexpected and emerging hazard of climate change. Sci Total Environ 476-477:165-180

Gleyzes C, Tellier S, Astruc M (2002) Fractionation studies of trace elements in contaminated soils and sediments: a review of sequential extraction procedures. Trac-Trend Anal Chem 21:451-467

Győri Z, Boros N, Sipos P, Bertáné Szabó E, Kovács K, Horváth M, Takács A, Heltai G (2015) Evaluation of the heavy metal content of the Upper Tisza River floodplain soils over the last decade. Hung J Ind Chem 43:19-23

Hofacker AF, Voegelin A, Kaegi R, Weber F-A, Kretzschmar R (2013) Temperature-dependent formation of metallic copper and metal sulfide nanoparticles during flooding of a contaminated soil. Geochim Cosmochim Ac 103:316-332

Hum L, Matschullat J (2002) Heavy metals and arsenic in the sediments of the River Tisza and her tributaries in autumn-winter 1999-2000. Hidrológiai Közlöny 82:23-30

Jahan S, Strezov V (2018) Comparison of pollution indices for the assessment of heavy metals in the sediments of seaports of NSW, Australia. Mar Pollut Bull 128:295-306

Kiss T (2014) Fluviális folyamatok antropogén hatásra megváltozó dinamikája: egyensúly és érzékenység vizsgálata folyóvizi környezetben. University of Szeged, Hungary, DSc Dissertation

Kiss T, Sándor A (2009) Land-use changes and their effect on floodplain aggradation along the Middle-Tisza River, Hungary. Acta Geographica Debrecina. Landscape Environ 3:1-10

Kraft C, von Tümpeling W, Zachmann DW (2006) The effects of mining in Northern Romania on the heavy metal distribution in sediments of the rivers Szamos and Tisza (Hungary). Acta Hydrochim Hydrobiol 34:257-264

Lakatos G, Fleit E, Mészáros I (2003) Ecotoxicological studies and risk assessment on the cyanide contamination in Tisza river. Toxicol Lett 140-141:333-342 
Liao J, Chen J, Ru X, Chen J, Wu H, Wei C (2017) Heavy metals in river surface sediments affected with multiple pollution sources, South China: Distribution, enrichment and source apportionment. J Geochem Explor 176:9-19

Ma Y, Lombi E, Oliver IW, Nolan AL, McLaughlin MJ (2006) Longterm aging of copper added to soils. Environ Sci Technol 40:6310 6317

Mezősi G (2011) The Physical Geography of Hungary. Akadémia Kiadó, Budapest, Hungary

Morse JW, Luther GW (1999) Chemical influences on trace metal-sulfide interactions in anoxic sediments. Geochim Cosmochim Ac 63: $3373-3378$

MSZ 21470-52:1983 (1983). Environmental protection. Testing of soils. Determination of organic matter. Hungarian Standard Association, Budapest, Hungary (in Hungarian)

MSZ-08-0206-2:1978 (1978). Evaluation of some chemical properties of the soil. Laboratory tests. ( $\mathrm{pH}$ value, phenolphtaleine alkalinity expressed in soda, all water soluble salts, hydrolite (y1-value) and exchanging acidity (y2- value)). Hungarian Standard Association. Budapest, Hungary (in Hungarian)

MSZ 20135:1999 (1999). Determination of the soluble nutrient element content of the soil. Hungarian Standard Association. Budapest, Hungary (in Hungarian)

Müller G (1979) Heavy metals in the sediment of the Rhine - Changes Seity. Umschau 79:778-783

Nguyen HL, Braun M, Szaloki I, Baeyens W, Grieken RV, Leermakers M (2009) Tracing the metal pollution history of the Tisza River through the analysis of a sediment depth profile. Water Air Soil Pollut 200: $119-132$

Ódor L, Horváth I, Fügedi U (1997) Low-density geochemical mapping in Hungary. J Geochem Explor 60:55-66

Osán J, Török S, Alföldy B, Alsecz A, Falkenberg G, Baik SY, Van Grieken R (2007) Comparison of sediment pollution in the rivers of the Hungarian Upper Tisza Region using non-destructive analytical techniques. Spectrochim Acta B 62:123-136

Óvári M, Mages M, Woelfl S, von Tuempling W, Kröpfl K, Záray G (2004) Total reflection X-ray fluorescence spectrometric determination of element inlets from mining activities at the upper Tisza catchment area, Hungary. Spectrochim Acta B 59:1173-1181

Passos EA, Alves JC, Dos Santos IS, Alves JPH, Garcia CAB, Spinola Costa AC (2010) Assessment of trace metals contamination in estuarine sediments using a sequential extraction technique and principal component analysis. Microchem J 96:50-57

Peltier E, Dahl AL, Gaillard J-F (2005) Metal speciation in anoxic sediments: when sulfides can be construed as oxides. Environ Sci Technol 39:311-316

Prokisch J, Széles É, Kovács B, Győri Z, Németh T, West L, Harper S, Adriano D (2009) Sampling strategies for testing and evaluation of soil contamination in riparian systems at the Tisza River basin, Hungary. Commun Soil Sci Plan 40:391-406

Pueyo M, Mateu J, Rigol A, Vidal M, López-Sánchez JF, Rauret G (2008) Use of the modified BCR three-step sequential extraction procedure for the study of trace element dynamics in contaminated soils. Environ Pollut 152:330-341

Sakan SM, Đorđević DS (2010) Evaluation of heavy metal contamination in sediments using the method of total digestion and determination of the binding forms-Tisa River Basin, Serbia. J Environ Sci Heal A 45:783-794
Sakan SM, Đorđević DS, Manojlović DD, Predrag PS (2009) Assessment of heavy metal pollutants accumulation in the Tisza river sediments. J Environ Manag 90:3382-3390

Sakan SM, Sakan NM, Đorđević DS (2013) Trace element study in Tisa River and Danube alluvial sediment in Serbia. Int J Sediment Res 28:234-245

Salomons W, Förstner U (1984) Metals in the Hydrocycle. SpringerVerlag, Berlin, Germany

Simon E, Kis O, Jakab T, Kolozsvári I, Málnás K, Harangi S, Baranyai E, Miskolczi M, Tóthmérész B, Dévai G (2017) Assessment of contamination based on trace element concentrations in Gomphus flavipes (Odonata: Insect) larvae of the Upper Tisza Region. Ecotoxicol Environ Safe 136:55-61

Soldán P, Pavonič M, Bouček J, Kokeš J (2001) Baia Mare accidentbrief ecotoxicological report of Czech Experts. Ecotoxicol Environ Safe 49:255-261

Szabó S, Posta J, Gosztonyi G, Mészáros I, Prokisch J (2008) Heavy metal content of flood sediments and plants near the River Tisza. Acta Geographica Debrecina: Landscape and Environment Series 2: 120-131

Szolnoki Z, Farsang A (2013) Evaluation of metal mobility and bioaccessibility in soils of urban vegetable gardens using sequential extraction. Water Air Soil Pollut 224:1737

Tamás M, Farsang A (2011) Evaluation of environmental condition: water and sediment examination of oxbow lakes. Acta Geographica Debrecina. Landscape Environ 5:84-92

Tomlinson DL, Wilson JG, Harris CR, Jeffrey DW (1980) Problems in the assessment of heavy-metal levels in estuaries and the formation of a pollution index. Helgol Mar Res 33:566-575

Ure AM, Quevauviller P, Muntau H, Griepink B (1993) Speciation of heavy metals in soils and sediments. An account of the improvement and harmonization of extraction techniques undertaken under the auspices of the BCR of the Commission of the European Communities. Int J Environ An Ch 51:135-151

Viers J, Dupré B, Gaillardet J (2009) Chemical composition of suspended sediments in World Rivers: New insights from a new database. Sci Total Environ 407:853-868

Weber F-A, Voegelin A, Kretzschmar R (2009) Multi-metal contaminant dynamics in temporarily flooded soil under sulfate limitation. Geochim Cosmochim Ac 73:5513-5527

Woelfl S, Mages M, Óvári M, Geller W (2006) Determination of heavy metals in macrozoobenthos from the rivers Tisza and Szamos by total reflection X-ray fluorescence spectrometry. Spectrochim Acta B 61:1153-1157

Wuana RA, Okieimen FE (2011) Heavy metals in contaminated soils: a review of sources, chemistry, risks and best available strategies for remediation. ISRN Ecology, Article ID 402647, 20 pp, https://doi. org/10.5402/2011/402647

Zhang C, Yu Z, Zeng G, Jiang M, Yang Z, Cui F, Zhu M, Shen L, Hu L (2014) Effects of sediment geochemical properties on heavy metal bioavailability. Environ Int 73:270-281

Zhang G, Bai J, Xiao R, Zhao Q, Jia J, Cui B, Liu X (2017) Heavy metal fractions and ecological risk assessment in sediments from urban, rural and reclamation-affected rivers of the Pearl River Estuary, China. Chemosphere 184:278-288

Publisher's note Springer Nature remains neutral with regard to jurisdictional claims in published maps and institutional affiliations. 